\title{
Minerals, Toxic Heavy Metals, and Antioxidant Properties of Honeys from Bangladesh
}

\author{
Sudip Paul, ${ }^{1}$ Md. Sakib Hossen, ${ }^{1}$ E. M. Tanvir, ${ }^{1,2}$ Rizwana Afroz, ${ }^{1}$ Delwar Hossen, ${ }^{1}$ \\ Sagarika Das, ${ }^{1}$ Nikhil Chandra Bhoumik, ${ }^{3}$ Nurul Karim, ${ }^{1}$ Farha Matin Juliana, ${ }^{1}$ \\ Siew Hua Gan, ${ }^{4}$ and Md. Ibrahim Khali1 ${ }^{1,4}$ \\ ${ }^{1}$ Laboratory of Preventive and Integrative Biomedicine, Department of Biochemistry and Molecular Biology, Jahangirnagar University, \\ Savar, Dhaka 1342, Bangladesh \\ ${ }^{2}$ Veterinary Drug Residue Analysis Division, Institute of Food \& Radiation Biology, Atomic Energy Research Establishment, \\ Savar, Dhaka 1349, Bangladesh \\ ${ }^{3}$ Wazed Miah Science Research Center, Jahangirnagar University, Dhaka 1342, Bangladesh \\ ${ }^{4}$ Human Genome Centre, School of Medical Sciences, Universiti Sains Malaysia, 16150 Kubang Kerian, Kelantan, Malaysia
}

Correspondence should be addressed to Md. Ibrahim Khalil; drmikhalil@gmail.com

Received 18 October 2016; Revised 17 February 2017; Accepted 20 February 2017; Published 7 March 2017

Academic Editor: Sevgi Kolaylı

Copyright (c) 2017 Sudip Paul et al. This is an open access article distributed under the Creative Commons Attribution License, which permits unrestricted use, distribution, and reproduction in any medium, provided the original work is properly cited.

\begin{abstract}
The study reports on major and trace elements as well as antioxidant properties of honey samples from Bangladesh. Four major cationic elements, seven trace elements, and three heavy metals were determined in the 12 honey samples using atomic absorption spectrophotometer. Nutritional values in these honey samples were further investigated according to their antioxidant properties. The content of major elements was in the range of $62.75-616.58,579.48-2219.43,69.42-632.25$, and $0.13-1.20 \mathrm{mg} / \mathrm{kg}$ for sodium, potassium, magnesium, and calcium, respectively. The trace elements varied in the range of $0.41-28,0.12-3.54,1.54-2.85,0.29-$ $0.59,0.02-0.35$, and $0.01-0.06 \mathrm{mg} / \mathrm{kg}$ for iron, zinc, copper, nickel, cobalt, and cadmium, respectively. Among the heavy metals, only lead $(0.17-2.19 \mathrm{mg} / \mathrm{kg})$ was detected. The results of antioxidant analysis based on phenolics, flavonoids, ascorbic acid, reducing sugar, and proteins (as nonphenolic antioxidants) revealed that multifloral raw honey samples contain significantly higher levels of reducing agents than monofloral and commercial brand honeys. The study provides a useful insight on the minerals, heavy metals, and antioxidant properties of honey samples commonly consumed in Bangladesh and found to be rich source of antioxidants and minerals. Some samples might pose some risk to the health due to lead contamination.
\end{abstract}

\section{Introduction}

Honey is a sweet, sticky fluid with varying color (including yellowish-brown, amber, light amber, extra light amber, and dark amber) made by the bees and other insects from the flower nectar $[1,2]$. It is one of the most complex foodstuffs, consists of at least 181 components, and is basically a concentrated solution of a complex mixture of sugars [3, 4]. According to honey quality and international regulatory standards, one of the most important criteria of honey quality is the mineral content along with its antioxidant potential [5] as it can influence the color and taste of honeys [6]. To date, 31 different minerals have been identified in different types of honey from various origins including all major minerals which are highly essential for human [7]. However, the quantity and diversity of minerals found in honeys are mainly dependent on the floral and geographical origins, the nutrients absorbed by the plants, their availability in the soil, and any possible contaminations of the soil and the environment [6]. Some toxic elements, such as lead, cadmium, and arsenic, might be present due to contamination from the surrounding environment [8-10]. Interestingly, honey is now considered as a predictor of environmental pollution, as indicated by its heavy metal content [11].

Considering the medicinal values, the important constituents of honey include enzymes, vitamins, organic acids, phenolics, flavonoids, and other phytochemicals, which contribute to its antioxidant properties [12]. To date, honey has 
been shown to confer significant protective effects against oxidative injuries of the liver, kidney, and rat myocardium with good antioxidant potential as previously reported $[4,13$, 14]. The components in honey responsible for its antioxidant effects are phenolic acids, flavonoids, ascorbic acid, catalase, peroxidase, carotenoids, and products of Maillard reactions [15]. Honey also possesses significant antibacterial and antifungal activities [16, 17]. Moreover, honey has been shown to exhibit synergistic effects against certain multidrug resistance bacterial species especially when used with other bee products like propolis [17]. However, the quality and quantity of these bioactive components vary widely depending on the floral and geographical origin of the honey. Processing, handling, and storage of honey may influence its antioxidant composition $[15,18]$.

Although different types of honey (generally categorized as monofloral and multifloral, raw, and commercial honey) have been widely consumed by the general public, there is a lack of comparative data to choose the best one. Therefore, our noble aim of this present study was to determine the mineral contents and toxic elements along with some basic antioxidant components of twelve samples of honey from Bangladesh.

\section{Methods and Materials}

2.1. Honey Samples. Twelve honey samples were collected from several different geographical areas of Bangladesh (Figure 1) between January 2012 and March 2014. Eight of the samples were raw honeys, while four were commercial honeys (Table 1). The raw samples were collected directly from the comb as well as the local apiary by experienced honey collectors while the commercial honey samples were purchased from departmental store in Dhaka, Bangladesh. Among the eight raw honey samples, five were multifloral and three were monofloral as confirmed by the suppliers. As for the commercial honey, three were multifloral while one was monofloral. All samples were stored in glass flasks at low temperature $\left(4^{\circ} \mathrm{C}\right)$ before analysis. All samples were analyzed within six months of collection.

2.2. Chemicals and Reagents. Gallic acid, benzoic acid, catechin, 1,1-diphenyl-2-picrylhydrazyl (DPPH), and 2,4,6-tris(2pyridyl)-1,3,5-triazine (TPTZ) were purchased from SigmaAldrich (St. Louis, Missouri, USA). All standards were purchased from Sigma-Aldrich Production, GmBH, Switzerland. All of the chemicals and reagents used in this study were of analytical grade.

\subsection{Sample Digestion for the Mineral and Trace Element} Content. The major and trace elements in the honey samples were analyzed following the standard method [19] with slight modifications. Briefly, $2 \mathrm{~g}$ of each honey sample was digested with perchloric acid $\left(\mathrm{HClO}_{4}\right)$ and hydrochloric acid $(\mathrm{HCl})$ in a ratio of $1: 2(\mathrm{~V} / \mathrm{V})$ on a hotplate (LMS1003, Daihan Labtech Corporation Ltd., Korea) to near dryness with the temperature controlled at $400^{\circ} \mathrm{C}$. The sample containing volumetric flask was cooled at room temperature before the addition of deionized water to the mark on the flask.
For the measurement of sodium, potassium, and magnesium, 100-fold diluted samples were filtered using a nylon membrane filter (Whatman, $0.8 \mu \mathrm{m}$ pore size, $47 \mathrm{~mm}$ diameter) and preserved for the determination of mineral and trace element content.

2.4. Mineral Analysis. In the present study, four major cationic elements, such as sodium $(\mathrm{Na})$, potassium $(\mathrm{K})$, calcium $(\mathrm{Ca})$, and magnesium $(\mathrm{Mg})$, and seven trace elements, including iron $(\mathrm{Fe})$, zinc $(\mathrm{Zn})$, copper $(\mathrm{Cu})$, cadmium $(\mathrm{Cd})$, molybdenum (Mo), cobalt (Co), and nickel (Ni), and three heavy metals, such as lead $(\mathrm{Pb})$, mercury $(\mathrm{Hg})$, and arsenic (As), were determined in the honey samples using an atomic absorption spectrophotometer (AA-7000, Shimadzu Corporation, Kyoto, Japan) coupled with an autosampler ASC 7000. Specifically, the element As was measured using the graphite furnace technique, and $\mathrm{Hg}$ was measured using cold vapor atomic absorption spectrometry; all of the other elements were measured using a direct absorption technique according to the standard guidelines of the manufacturer.

2.5. Instrumentation. The major operating conditions that were used are presented in Table 2. A blank solution was prepared under similar conditions, and the mean signal of the blank solution was subtracted from the analytical signals of the honey samples, as automatically performed by the instrument. Background correction (BCG) was performed using the BGC-D2 (D2 lamp method; high speed, dual frequency simultaneous measurement) method. The optimum analytical range was 0.5 to 1.0 absorbance units, with coefficients of variation that ranged between 0.05 and $0.40 \%$. Determination was made on a dry weight basis for all of the samples. The results were calculated and expressed as $\mathrm{mg} / \mathrm{kg}$ of honey.

2.6. Preparation of Standards and Calibration Curve. The standard stock solutions of $\mathrm{Na}, \mathrm{K}, \mathrm{Mg}, \mathrm{Fe}, \mathrm{Ca}, \mathrm{Zn}, \mathrm{Cu}, \mathrm{Pb}$, $\mathrm{Cd}, \mathrm{As}, \mathrm{Mo}, \mathrm{Co}, \mathrm{Ni}$, and $\mathrm{Hg}$ were prepared $(1000 \mathrm{mg} / \mathrm{L})$, and the amount of minerals in each sample type was calculated based on the slope of the standard curve, which was prepared as previously described [20].

2.7. Quality Control and Quality Assurance. The method was validated for accuracy and precision in accordance with the European Commission (EC) guidelines [21]. The accuracy was measured by analyzing and comparing the samples with measured values of known spiked samples. The precision was expressed as the relative standard deviation (RSD). The percentage recovery was calculated using the following formula:

Percentage recovery $=[\mathrm{CE} / \mathrm{CM} \times 100]$, where $\mathrm{CE}$ is the experimental concentration determined from the calibration curve and $\mathrm{CM}$ is the spiked concentration. The mean percentage recovery of the method ranged from $88.0 \%$ to $105.0 \%$, while the mean precision ranged from $4 \%$ to $10 \%$.

2.8. Antioxidant Properties. The total polyphenol (TPP) content of the honey samples was estimated by spectrometric determination based on Folin-Ciocalteu's method [22] 

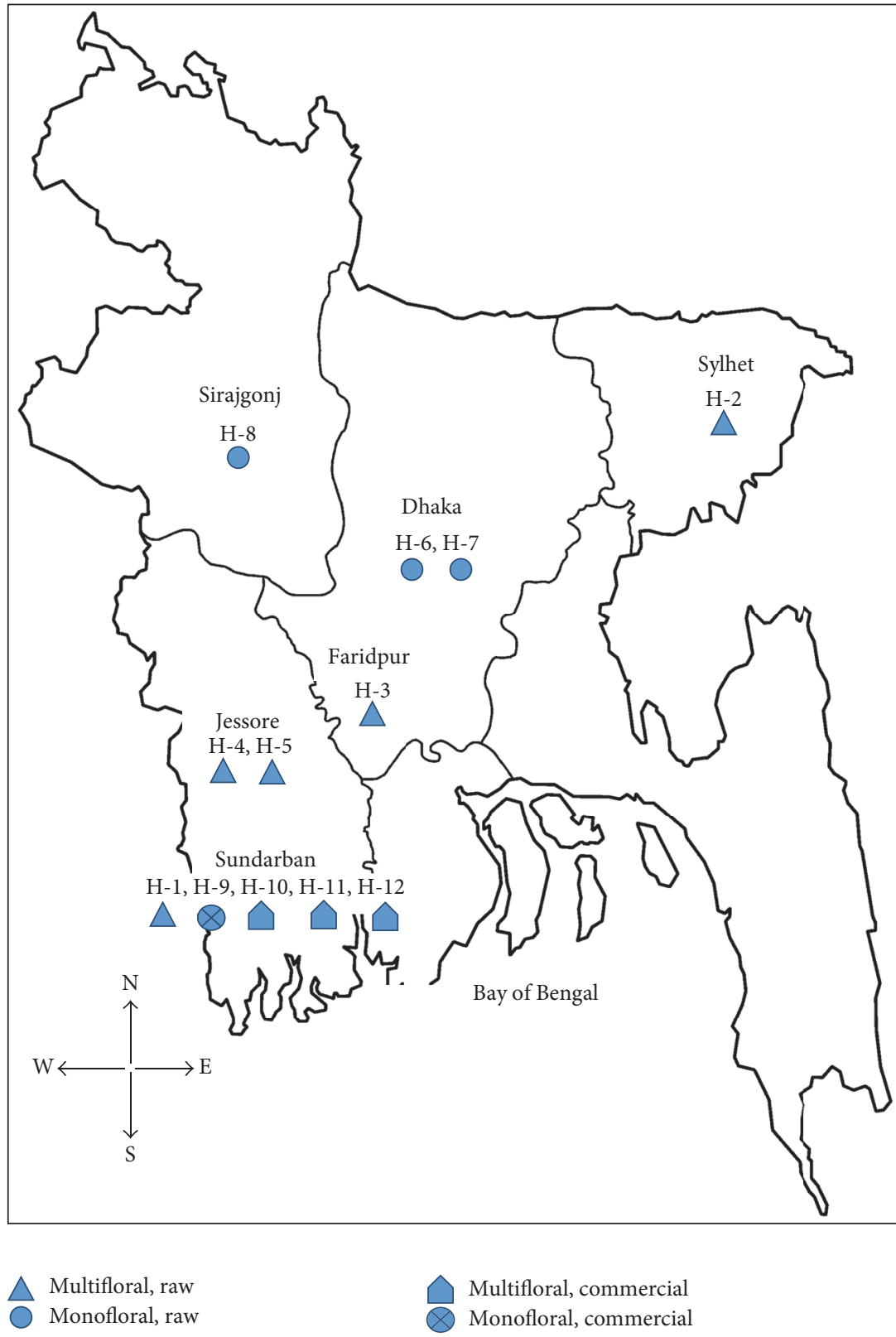

Figure 1: Geological locations of honey samples collected in this study.

using a PD-303S spectrophotometer (APEL, Japan). The TPP content was determined in terms of gallic acid equivalents (GAEs) and expressed as mg of GAEs/kg of honey. The total flavonoid (TF) content was estimated using an aluminum chloride colorimetric assay [23]. The concentration of TF was determined by catechin equivalents (CEs) and the results were expressed as $\mathrm{mg}$ of $\mathrm{CEs} / \mathrm{kg}$ of honey. The ascorbic acid (AA) content of the honey samples was estimated by a method that was previously established by Omaye et al. [24]. The AA content was expressed as $\mathrm{mg}$ of ascorbate equivalents (AEs) per $g$ of honey. The reducing sugars content was estimated according to the Nelson-Somogyi method [25]. The reducing sugar content was expressed as $g$ of D-glucose per $100 \mathrm{~g}$ of honey.
2.9. Total Protein Content. The total protein content in the honey samples was estimated using Lowry's method [26]. The final results are expressed as $\mathrm{mg}$ bovine serum albumin (BSA) equivalents per $\mathrm{g}$ of honey.

\subsection{Antioxidant Activity Analysis}

2.10.1. DPPH Free Radical Scavenging Activity. The percentage of antioxidant activity in each type of honey sample was assessed using a DPPH free radical assay. DPPH radical scavenging activity was measured based on an established method by Braca et al. [27]. DPPH scavenging activity is expressed as the concentration of sample that is required to scavenge DPPH and decrease the absorbance by $50 \%\left(\mathrm{SC}_{50}\right)$. The value can be graphically determined by plotting the 
TABLE 1: Honey samples from the different regions of Bangladesh.

\begin{tabular}{lcccc}
\hline Samples & Code name & Geographical location & Collection period & Class \\
\hline Sundarban honey & H-1 & Sundarban, Khulna & January, 2012 & Raw Multifloral (RMF) \\
Sylhet honey & H-2 & Sylhet & January, 2012 & Raw Multifloral (RMF) \\
Faridpur honey & H-3 & Faridpur & May, 2012 & Raw Multifloral (RMF) \\
Jessore honey-1 & H-4 & Jessore & July, 2012 & Raw Multifloral (RMF) \\
Jessore honey-2 & H-5 & Jessore & July, 2012 & Raw Multifloral (RMF) \\
Black cumin seed & H-6 & Savar, Dhaka & March, 2014 & Raw Monofloral (RMnF) \\
Boroi (Chinese date) & H-7 & Savar, Dhaka & March, 2014 & Raw Monofloral (RMnF) \\
Mustard & H-8 & Sirajgonj & June, 2012 & Raw Monofloral (RMnF) \\
Commercial Brand-1 & H-9 & Sundarban, Khulna & March, 2014 & Commercial Monofloral (CMnF) \\
Commercial Brand-2 & H-10 & Sundarban, Khulna & March, 2014 & Commercial Multifloral (CMF) \\
Commercial Brand-3 & H-11 & Sundarban, Khulna & March, 2014 & Commercial Multifloral (CMF) \\
Commercial Brand-4 & H-12 & Sundarban, Khulna & March, 2014 & Commercial Multifloral (CMF) \\
\hline
\end{tabular}

absorbance (the percentage of inhibition of DPPH radicals) against the log concentration of DPPH and determining the slope of the nonlinear regression.

2.10.2. Ferric Reducing Antioxidant Power Assay. A ferric reducing antioxidant power (FRAP) assay was performed and measured according to a method established by Benzie and Strain [28]. A standard curve was plotted using an aqueous solution of ferrous sulfate $\left(\mathrm{FeSO}_{4} \cdot 7 \mathrm{H}_{2} \mathrm{O}\right)(100-$ $1000 \mu \mathrm{M})$, with FRAP values expressed as micromoles of ferrous equivalent ( $\mu \mathrm{M}$ Fe [II] per kg of sample).

2.11. Statistical Analysis. All of the experiments were performed in triplicate, and the results were expressed as the mean values \pm standard deviation $(\mathrm{SD})$. The $\mathrm{SC}_{50}$ value was calculated by a regression analysis. The significant differences represented by the letters were obtained via a one-way analysis of variance (ANOVA) followed by Tukey's honestly significant difference (HSD) post hoc test $(p<0.05)$. The data were analyzed using SPSS (Statistical Packages for Social Science, version 22.0, IBM Corporation, New York, USA) and Microsoft Excel 2013 (Redmond, Washington, USA).

\section{Results and Discussion}

To the best of our knowledge, this investigation is the first to report mineral and trace element concentrations along with major phytochemical constituents of monofloral and multifloral origins from different geographical areas of Bangladesh. The data can be used to promote a more widespread use of best nutritious honey with special emphasis on its medicinal properties.

3.1. Mineral and Trace Elements. A total of 14 elements were analyzed, with the most abundant being $\mathrm{Na}, \mathrm{K}, \mathrm{Mg}, \mathrm{Ca}, \mathrm{Fe}$, $\mathrm{Zn}, \mathrm{Co}, \mathrm{Cd}, \mathrm{Ni}$, and $\mathrm{Pb}$, all of which were detected in most of the honey samples. Toxic elements, such as As and $\mathrm{Hg}$, and nontoxic Mo were not found in any of the samples. The results and statistical analyses of the major elements are shown in Table 3.
Overall, the honey samples from Bangladesh had high $\mathrm{Na}$ levels. The average concentration of $\mathrm{Na}$ ranged between 62.75 and $616.58 \mathrm{mg} / \mathrm{kg}$ as compared to $\mathrm{Na}$ concentrations of honey from Saudi Arabia and Middle Anatolia and Western Anatolia, Turkey, which were reported to range between 15.69 and $26.93 \mathrm{mg} / \mathrm{kg}, 9.34$ and $45.9 \mathrm{mg} / \mathrm{kg}$, and 320.7 and $621.1 \mathrm{mg} / \mathrm{kg}$, respectively [29-31]. Nevertheless, the mean value of $\mathrm{Na}$ in these samples was higher than the mean values reported for Turkey (117 mg/kg), Spain (99.7 mg/kg), and Italy $(96 \mathrm{mg} / \mathrm{kg}$ ) but lower than the samples from Egypt (378 mg/kg) [32].

The results indicated that the honey samples from Bangladesh had high $\mathrm{K}$ levels, which ranged from $579.48 \pm$ 1.33 to $2219.43 \pm 4.68 \mathrm{mg} / \mathrm{kg}$, (Table 3 ) with approximately $30 \%$ of the values exceeding $1000 \mathrm{mg} / \mathrm{kg}$. Overall, the mean level was higher than those reported from Anatolia, Turkey $(296 \mathrm{mg} / \mathrm{kg}$ ) [33], and the Latium region, Italy $(472 \mathrm{mg} / \mathrm{kg})$ [34], but lower than honey from Egypt $(1500 \mathrm{mg} / \mathrm{kg})$ [32].

The $\mathrm{Mg}$ level was also at a high concentration for most of the analyzed samples, ranging between $69.42 \pm$ 0.38 and $632.25 \pm 2.33 \mathrm{mg} / \mathrm{kg}$. Generally, the levels are higher than those reported for Malaysian honey samples (21.83 to $199.33 \mathrm{mg} / \mathrm{kg}$ ) [35] and Italian honey samples $(22.2$ to $159.0 \mathrm{mg} / \mathrm{kg}$ ) [36], with the mean value $177.90 \mathrm{mg} / \mathrm{kg}$ higher than honey from Argentina $(23.38 \mathrm{mg} / \mathrm{kg})$, Turkey (136 mg/kg), and Egypt (102 mg/kg) [32]. Nevertheless, the Ca level (mean level $0.73 \mathrm{mg} / \mathrm{kg}$ ) of the investigated honey samples was significantly lower than that of honey samples from Argentina (56.35 mg/kg), Turkey (51 mg/kg), and Egypt (192 mg/kg) [32].

In addition to having high $\mathrm{Na}, \mathrm{K}$, and $\mathrm{Mg}$ levels, the honey samples from Bangladesh also contained adequate amounts of other essential trace elements, including $\mathrm{Fe}, \mathrm{Zn}$, $\mathrm{Cu}$, and $\mathrm{Co}$, when compared to those previously reported in different countries. The Fe (mean: $4.10 \mathrm{mg} / \mathrm{kg}$ ) and $\mathrm{Zn}$ (mean: $0.89 \mathrm{mg} / \mathrm{kg}$ ) contents vary moderately with the different countries' honey samples, for Siena, Italy (mean Fe $=3.8 \mathrm{mg} / \mathrm{kg}$ and $\mathrm{Zn}=2.5 \mathrm{mg} / \mathrm{kg}$ ), for Latium, Italy (mean $\mathrm{Fe}=4.5 \mathrm{mg} / \mathrm{kg}$ and $\mathrm{Zn}=3.5 \mathrm{mg} / \mathrm{kg}$ ), for Turkey (mean $\mathrm{Fe}=6.6 \mathrm{mg} / \mathrm{kg}$ and $\mathrm{Zn}=2.7 \mathrm{mg} / \mathrm{kg}$ ), for Egypt (mean 


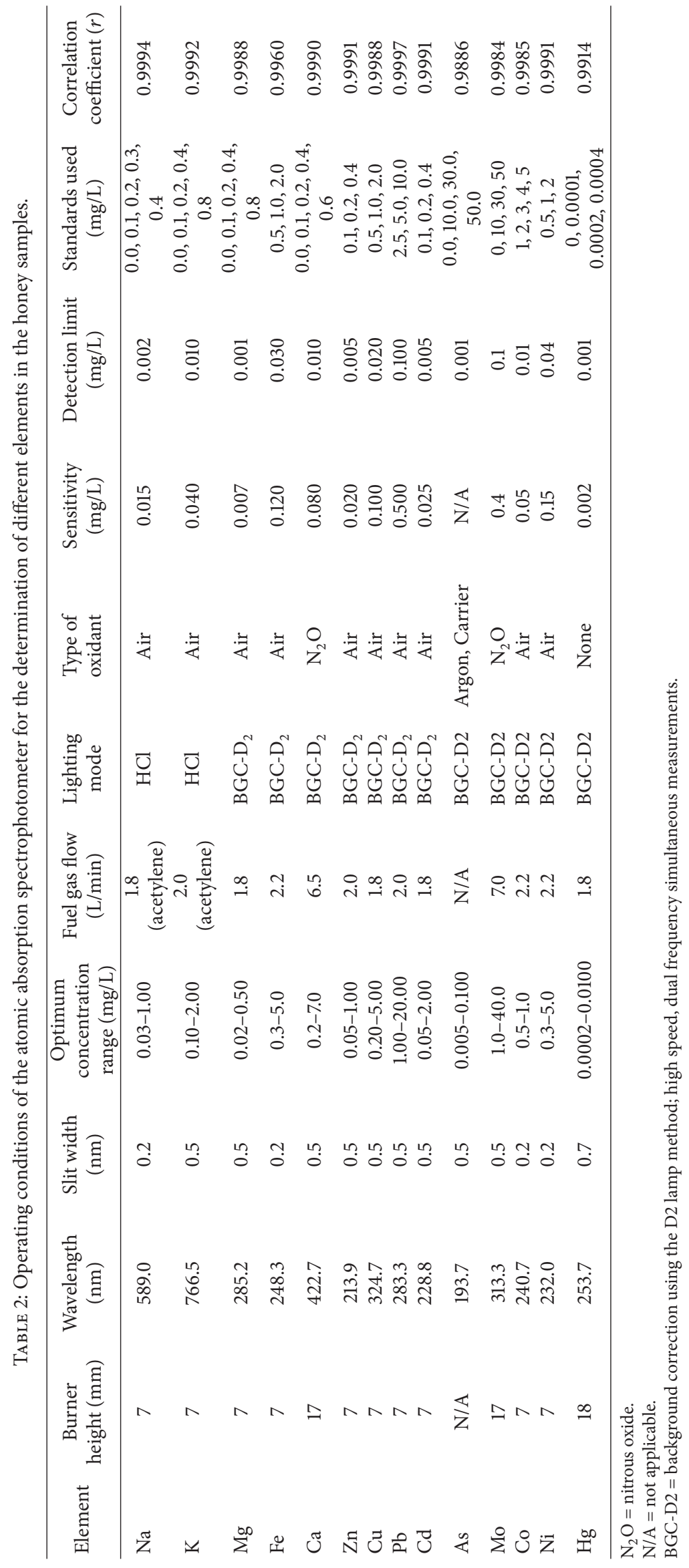


TABLE 3: Mineral content of the honey samples from Bangladesh.

\begin{tabular}{lcccr}
\hline Sample & $\mathrm{Na}(\mathrm{mg} / \mathrm{kg})$ & $\mathrm{K}(\mathrm{mg} / \mathrm{kg})$ & $\mathrm{Mg}(\mathrm{mg} / \mathrm{kg})$ & $\mathrm{Ca}(\mathrm{mg} / \mathrm{kg})$ \\
\hline $\mathrm{H}-1$ & $616.58 \pm 1.17$ & $2219.43 \pm 4.68$ & $632.25 \pm 2.33$ & $1.133 \pm 0.020$ \\
$\mathrm{H}-2$ & $203.64 \pm 1.26$ & $1024.22 \pm 1.57$ & $209.42 \pm 0.83$ & $0.133 \pm 0.002$ \\
$\mathrm{H}-3$ & $121.21 \pm 0.69$ & $1254.35 \pm 2.43$ & $163.92 \pm 0.78$ & $1.067 \pm 0.030$ \\
H-4 & $108.99 \pm 0.50$ & $889.21 \pm 1.24$ & $201.42 \pm 1.67$ & $1.058 \pm 0.020$ \\
H-5 & $126.40 \pm 0.83$ & $1017.55 \pm 1.15$ & $141.58 \pm 0.81$ & $0.825 \pm 0.010$ \\
H-6 & $112.39 \pm 1.67$ & $876.72 \pm 1.67$ & $128.00 \pm 0.76$ & $0.583 \pm 0.010$ \\
H-7 & $100.06 \pm 1.23$ & $778.32 \pm 1.71$ & $156.25 \pm 0.89$ & $1.200 \pm 0.010$ \\
H-8 & $124.49 \pm 1.38$ & $694.98 \pm 1.01$ & $69.42 \pm 0.38$ & $0.267 \pm 0.003$ \\
H-9 & $62.75 \pm 0.91$ & $579.48 \pm 1.33$ & $71.58 \pm 0.56$ & $0.342 \pm 0.007$ \\
H-10 & $80.96 \pm 0.57$ & $648.67 \pm 1.11$ & $88.67 \pm 0.27$ & $0.692 \pm 0.008$ \\
H-11 & $112.43 \pm 1.33$ & $916.34 \pm 1.42$ & $97.58 \pm 0.17$ & $0.667 \pm 0.005$ \\
H-12 & $199.17 \pm 1.73$ & $756.88 \pm 1.37$ & 177.90 & $0.842 \pm 0.010$ \\
Mean & 164.08 & 971.34 & $69.42-632.25$ & 0.73 \\
Range & $62.75-616.58$ & $579.48-2219.43$ & & $0.13-1.20$ \\
\hline
\end{tabular}

$\mathrm{Fe}=113.3 \mathrm{mg} / \mathrm{kg}$ and $\mathrm{Zn}=7.2 \mathrm{mg} / \mathrm{kg}$ ), and for Spain (mean $\mathrm{Fe}=4.56 \mathrm{mg} / \mathrm{kg}$ and $\mathrm{Zn}=2.12 \mathrm{mg} / \mathrm{kg}$ ) $[20,32,33,36,37]$.

$\mathrm{Cu}$ was detected in all of the honey samples (ranging between $1.54 \pm 0.08$ and $2.85 \pm 0.09 \mathrm{mg} / \mathrm{kg}$ ), which is lower than that reported for honey samples from Croatia (36.0 to $42.1 \mathrm{mg} / \mathrm{kg}$ ) [38]. For Co, low concentrations were detected in approximately $50 \%$ of the samples, ranging from $0.02 \pm 0.00$ to $0.35 \pm 0.00 \mathrm{mg} / \mathrm{kg}$, which is much lower than previously reported for Indian honey $(1.22 \mathrm{mg} / \mathrm{kg}$ ) [39]. Cd was detected in most of the analyzed samples, with concentrations ranging from $0.006 \pm 0.001$ to $0.06 \pm 0.01 \mathrm{mg} / \mathrm{kg}$. This value is also lower when compared to honey samples from Turkey ( 0.90 to $17.90 \mathrm{mg} / \mathrm{kg}$ ) [40]. $\mathrm{Ni}$ and $\mathrm{Pb}$ were also detected in all of the investigated honey samples at values that ranged from $0.29 \pm$ 0.00 to $0.59 \pm 0.03$ as well as $0.17 \pm 0.01$ to $2.19 \pm 0.03 \mathrm{mg} / \mathrm{kg}$, respectively. Meanwhile, the contents of trace elements in honeys from different regions of Turkey were in the range of 0.0026 to $0.0299 \mathrm{mg} / \mathrm{kg}(\mathrm{Ni})$ and $0.084-0.1058 \mathrm{mg} / \mathrm{kg}(\mathrm{Pb})$ [40].

It is very important to analyze the content of heavy metals such as trace elements in honey samples because of their toxicity and because they can be transported through the root system into the nectar or to the surfaces of the leaves. Most importantly, As, $\mathrm{Hg}$, and Mo were not detected in the investigated honey samples (Table 4), which indicates that the honey samples from Bangladesh were not very affected by environmental contamination. In comparison, As was detected in some of the honey samples from Malaysia [35].

\subsection{Antioxidant Properties}

3.2.1. Polyphenols. Dietary polyphenols have received tremendous attention among nutritionists, food scientists, and consumers because of their high antioxidant capacity (free radical scavenging and metal chelating activities) [41] and their possible beneficial implications to human health, such as in the treatment and prevention of cancer, cardiovascular disease, neurodegenerative disease, and other diseases [4244].
Due to the variation in the botanical origin and storage time duration, the composition, appearance, and concentration of phenolic substances in different honey samples are variable $[9,45]$. In our investigation, the polyphenol content ranged from $208.24 \pm 4.24 \mathrm{GAEs} \mathrm{mg} / \mathrm{kg}$ to $882 \pm 0.00 \mathrm{GAEs}$ $\mathrm{mg} / \mathrm{kg}$ (Table 5 ). In comparison, in another study by Islam et al. [9] from Bangladesh on eight different honey samples, the TPP levels were lower, ranging between 152.4 and $688.5 \mathrm{mg}$ of GAEs/kg.

3.2.2. Flavonoids. Flavonoids are potent antioxidants, free radical scavengers, metal ion chelators, and inhibitors of lipid peroxidation [46]. In this study, all of the honey samples from Bangladesh had lower flavonoid content (mean 71.88 CEs $\mathrm{mg} / \mathrm{kg}$; range $9.52-124.40 \mathrm{mg}$ of CEs/kg) (Table 5) than phenolic content because flavonoids are a subclass of polyphenols. However, the flavonoid content of the Bangladesh samples was higher than those from other countries, such as from Malaysia (11.52-34.55 mg/kg) [12], which indicates that the honey samples from Bangladesh have a good antioxidant potential.

3.2.3. Ascorbic Acid. AA, an essential nutrient for humans and some other animals, is the most abundant soluble antioxidant found in plants as well [47], and it directly interacts with a broad spectrum of reactive oxygen species (ROS). Following the interaction, the chain reaction that is initiated by free radicals is terminated via electron transfer; it is also involved in the regeneration of vitamin $\mathrm{E}$ [48]. In this study, the AA content of the samples was high (ranging between $0.25 \pm 0.01$ and $0.85 \pm 0.05 \mathrm{mg} / \mathrm{g}$ ). In comparison, the AA content of Portuguese, Nigerian, and Tualang honey samples was reported to be between 0.140 and $0.146 \mathrm{mg} / \mathrm{g}$ [49], 0.18 and $0.25 \mathrm{mg} / \mathrm{g}$, and 0.14 and $0.36 \mathrm{mg} / \mathrm{g}$ [50], respectively. Among the samples analyzed, raw-multifloral honey of Sylhet region contained the highest level of AA while lower amount was reported in raw-monofloral honey from Dhaka and Sirajgonj regions as well as in commercial-multifloral honey of Khulna region. TPP is sensitive to phenols and 


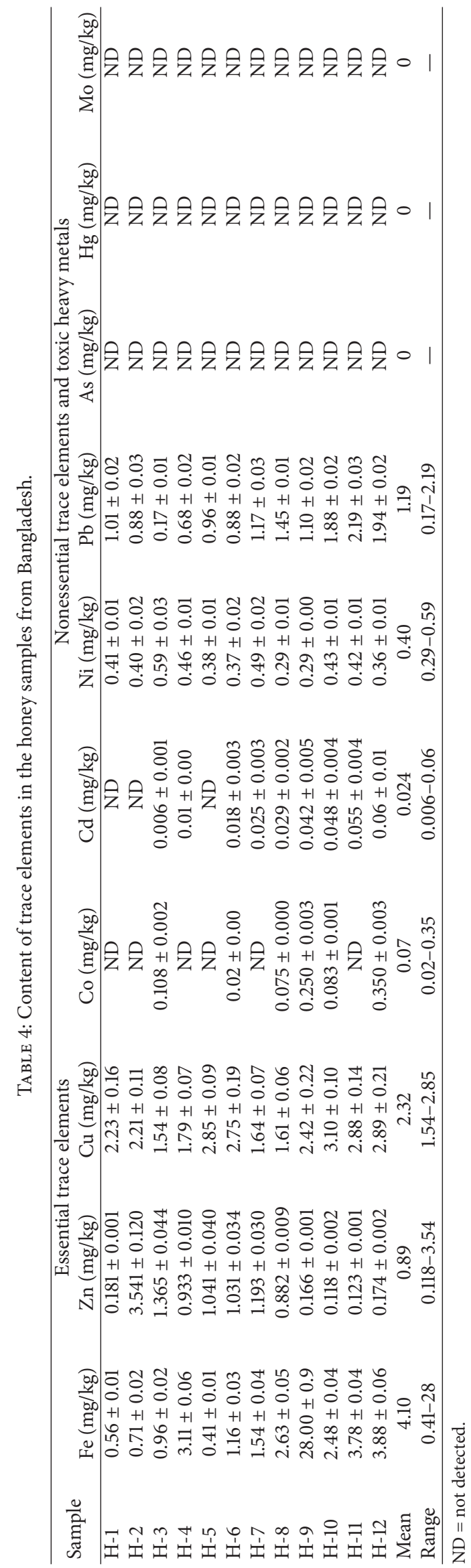




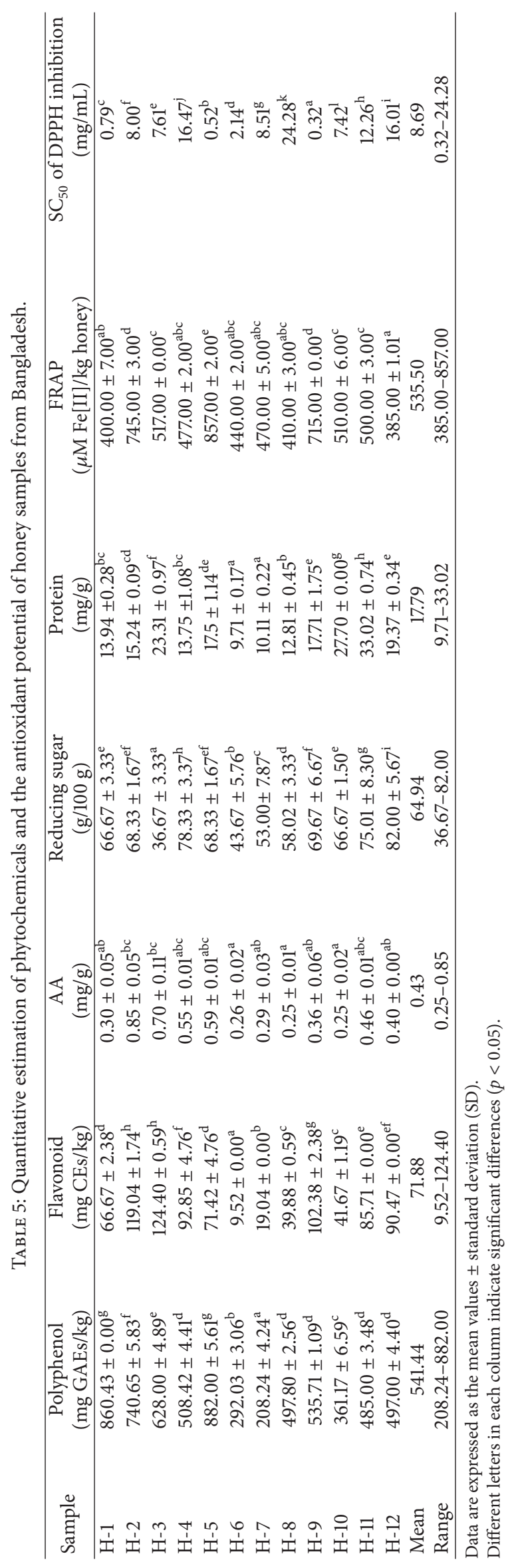


polyphenol compounds as well as other electron-donating antioxidants such as AA and tocopherols [18]. However, estimation of AA content is a direct measure of the level of water-soluble antioxidant in honey. The AA content in the honey samples from Bangladesh indicates that honey samples from Bangladesh can be used as an inexpensive and simple source of antioxidants.

3.2.4. Reducing Sugar. Honey is a complex mixture, with carbohydrates (sucrose, fructose, and maltose) being the main component while protein, water, minerals, vitamins, and antioxidants made up the remainder [9]. Reducing sugars are the major soluble sugars found in different types of honey. The reducing sugar content of the samples ranged from $36.67 \pm 3.33$ to $82.00 \pm 5.67 \mathrm{~g} / 100 \mathrm{~g}$. In comparison, the reducing sugar content of the honey samples from six different states in Northeastern Nigeria was $69.56 \pm 0.99$ to $75.83 \pm 9.36 \mathrm{~g} / 100 \mathrm{~g}[51]$.

3.2.5. Protein. The honey samples in this study had a high protein content (ranging between $9.71 \pm 0.17$ and $33.02 \pm$ $0.74 \mathrm{mg} / \mathrm{g}$ ). The high variability seen is partially due to the fact that the samples were collected from different sources. The variability in protein content of different honey samples has also been reported in other studies; for example, the protein content in Indian honey samples was reported to be 0.48 to $2.29 \mathrm{mg} / \mathrm{g}$; however in samples from Pakistan, the content was 2.07 to $4.07 \mathrm{mg} / \mathrm{g}[52,53]$. Although the specific proteins and enzymes were not measured, the higher protein content present in the honey samples from Bangladesh indicates a high presence of proteins and enzymes.

3.2.6. DPPH Free Radical Scavenging Activity. The DPPH radical scavenging test is one of the fastest tests available to screen the antioxidant properties of any sample by investigating the overall hydrogen/electron-donating activity of single antioxidant, and it also indicates the content of the healthpromoting dietary antioxidant supplements $[12,54,55]$. There were significant differences among the honey samples in terms of their scavenging abilities (Table 3). The reasons behind the markedly variable radical scavenging capacity that is exhibited by different types of honey are probably due to their diverse botanical origins [12]. The $\mathrm{SC}_{50}$ value of the honey samples was almost similar to the Malaysian honey samples, which ranged between 0.05 and $18.58 \mathrm{mg} / \mathrm{mL}$ [12].

3.2.7. FRAP Values. FRAP assay is a widely used method for determination of antioxidant potentials, because it directly gives an estimation of the antioxidants or reductants that are present in a sample and is based on the ability of the analyte to reduce the $\mathrm{Fe}^{3+} / \mathrm{Fe}^{2+}$ pair [12]. Out of the 12 honey types, the highest FRAP value was found in sample $\mathrm{H}-5$, which is a multifloral honey $(857 \pm 2.00 \mu \mathrm{M} \mathrm{Fe}[\mathrm{II}] / \mathrm{kg}$ honey), while the lowest value was found in commercial honey H-12 (385 $\pm 1.01 \mu \mathrm{M} \mathrm{Fe}[\mathrm{II}] / \mathrm{kg}$ honey) (Table 5). In comparison, a previous study of different honey samples from different origins stated a wide range of FRAP values, such as Tualang (706.91-892.15 $\mu \mathrm{M}$ Fe (II)/kg), Manuka $(363.38 \mu \mathrm{M}$
Fe (II) $/ \mathrm{kg}$ ), Borneo tropical ( $492.04 \mu \mathrm{M}$ Fe (II) $/ \mathrm{kg}$ ), Gelam (644.28 $\mu \mathrm{M} \mathrm{Fe}(\mathrm{II}) / \mathrm{kg})$ [12], Indian forest $(733.5 \mu \mathrm{M} \mathrm{Fe}$ (II) $/ \mathrm{kg}$ ), and pineapple honeys $(279.92 \mu \mathrm{M} \mathrm{Fe}$ (II) $/ \mathrm{kg}$ ) [56]. Overall, the honey samples from Bangladesh have high free scavenging activities as confirmed by their high FRAP values when compared to the honey samples from other countries.

3.3. Comparison within 12 Honey Samples from Bangladesh. The twelve honey samples were classified into four classes, as follows: (a) raw-multifloral (RMF), (b) commercialmultifloral (CMF), (c) raw-monofloral (RMnF), and (d) commercial monofloral (CMnF). Our investigated data indicates that all of the classes of honey not only have adequate amounts of phytoconstituents but also have sufficient antioxidant activity.

Among the four classes of honey, the phytoconstituents and antioxidant activities varied moderately from one another. The phytoconstituents and antioxidant activities of these four classes of honey decreased in the following order: for TPP: $\mathrm{RMF}>\mathrm{CMnF}>\mathrm{CMF}>\mathrm{RMnF}$, for TF: $\mathrm{CMnF}>\mathrm{RMF}$ $>\mathrm{CMF}>\mathrm{RMnF}$, for TP: $\mathrm{CMF}>\mathrm{CMnF}>\mathrm{RMF}>\mathrm{RMnF}$, for AA: $\mathrm{RMF}>\mathrm{CMF}>\mathrm{CMnF}>\mathrm{RMnF}$, for reducing sugar: $\mathrm{CMF}$ $>\mathrm{CMnF}>\mathrm{RMF}>\mathrm{RMnF}$, for FRAP: $\mathrm{CMnF}>\mathrm{RMF}>\mathrm{CMF}>$ RMnF, and for DPPH: CMF $>$ RMnF $>$ RMF $>$ CMnF.

Our study also indicates that natural multifloral honey samples contain high amounts of $\mathrm{Na}, \mathrm{K}, \mathrm{Ca}, \mathrm{Mg}$, and $\mathrm{Zn}$ compared with the other remaining three classes of honey but have low amounts of Fe. Fe was reported to be significantly higher in the CMnF class. Among the trace elements, As, Co, and Mo were totally absent in all four honey classes, while other elements were present in significantly lower amounts. Among the trace elements, $\mathrm{Co}, \mathrm{Pb}$, and $\mathrm{Cd}$ were present in lower amounts in the RMF class, and $\mathrm{Co}, \mathrm{Cu}, \mathrm{Ni}, \mathrm{Pb}$, and $\mathrm{Cd}$ were present in the highest amount in the CMF, CMnF, RMF, CMF, and CMF, respectively.

Finally, the findings on the four classes of honey samples from Bangladesh show that each class of honey has a good level of nutritional values because they have a high level of antioxidant activity and major elements and a significantly low amount of toxic heavy metals as well. Moreover, our study also reveals that the RMF and CMF classes contain a slightly higher nutritional value compared with the other two classes.

\section{Conclusions}

The findings of this study indicate that the raw-multifloral and commercial monofloral honey samples contained high amounts of antioxidants and essential minerals when compared with the raw-monofloral and commercial-multifloral honey samples. There were minimal contamination of the samples with toxic heavy metals like lead which might pose some risks to the health.

\section{Competing Interests}

The authors declare that there is no conflict of interests. 


\section{Acknowledgments}

The authors acknowledge the technical support provided by the Wazed Miah Science Research Center, Jahangirnagar University, and Mushroom Development Center, Savar, Dhaka, Bangladesh.

\section{References}

[1] F. W. Sladen, The Humble-Bee, Cambridge University Press, Cambridge, UK, 2014.

[2] N. AL-Waili, A. Al Ghamdi, M. J. Ansari, Y. Al-Attal, A. AlMubarak, and K. Salom, "Differences in composition of honey samples and their impact on the antimicrobial activities against drug multiresistant bacteria and pathogenic fungi," Archives of Medical Research, vol. 44, no. 4, pp. 307-316, 2013.

[3] S. G. Musharraf, S. Ambreen Fatima, A. J. Siddiqui, M. Iqbal Choudhary, and A. Atta-ur-Rahman, " ${ }^{1} \mathrm{H}-\mathrm{NMR}$ fingerprinting of brown rice syrup as a common adulterant in honey," Analytical Methods, vol. 8, no. 34, pp. 6444-6451, 2016.

[4] R. Afroz, E. M. Tanvir, M. F. Hossain et al., "Protective effect of Sundarban honey against acetaminophen-induced acute hepatonephrotoxicity in rats," Evidence-based Complementary and Alternative Medicine, vol. 2014, Article ID 143782, 8 pages, 2014.

[5] S. Bogdanov, C. Lüllmann, P. Martin et al., "Honey quality and international regulatory standards: review by the international honey commission," Bee World, vol. 80, no. 2, pp. 61-68, 1999.

[6] M. L. González-Miret, A. Terrab, D. Hernanz, M. Á. FernándezRecamales, and F. J. Heredia, "Multivariate correlation between color and mineral composition of honeys and by their botanical origin," Journal of Agricultural and Food Chemistry, vol. 53, no. 7, pp. 2574-2580, 2005.

[7] M. Mijanur Rahman, S. H. Gan, and M. I. Khalil, "Neurological effects of honey: current and future prospects," Evidence-based Complementary and Alternative Medicine, vol. 2014, Article ID 958721, 13 pages, 2014.

[8] E. Huskisson, S. Maggini, and M. Ruf, "The role of vitamins and minerals in energy metabolism and well-being," Journal of International Medical Research, vol. 35, no. 3, pp. 277-289, 2007.

[9] A. Islam, I. Khalil, N. Islam et al., "Physicochemical and antioxidant properties of Bangladeshi honeys stored for more than one year," BMC Complementary and Alternative Medicine, vol. 12, no. 1, article 177, p. 1, 2012.

[10] Y. Lu, H. Yao, D. Shan, Y. Jiang, S. Zhang, and J. Yang, "Heavy metal residues in soil and accumulation in maize at longterm wastewater irrigation area in Tongliao, China," Journal of Chemistry, vol. 2015, Article ID 628280, 9 pages, 2015.

[11] K. C. Jones, "Honey as an indicator of heavy metal contamination," Water, Air, and Soil Pollution, vol. 33, no. 1-2, pp. 179-189, 1987.

[12] M. I. Khalil, N. Alam, M. Moniruzzaman, S. A. Sulaiman, and S. H. Gan, "Phenolic acid composition and antioxidant properties of malaysian honeys," Journal of Food Science, vol. 76, no. 6, pp. C921-C928, 2011.

[13] E. M. Tanvir, R. Afroz, M. A. Z. Chowdhury et al., "Honey has a protective effect against chlorpyrifos-induced toxicity on lipid peroxidation, diagnostic markers and hepatic histoarchitecture," European Journal of Integrative Medicine, vol. 7, no. 5, pp. 525-533, 2015.
[14] M. I. Khalil, E. M. Tanvir, R. Afroz, S. A. Sulaiman, and S. H. Gan, "Cardioprotective effects of tualang honey: amelioration of cholesterol and cardiac enzymes levels," BioMed Research International, vol. 2015, Article ID 286051, 8 pages, 2015.

[15] R. Afroz, E. M. Tanvir, S. Paul, N. C. Bhoumik, S. H. Gan, and M. I. Khalil, "DNA damage inhibition properties of sundarban honey and its phenolic composition," Journal of Food Biochemistry, vol. 40, no. 4, pp. 436-445, 2016.

[16] M. J. Ansari, A. Al-Ghamdi, S. Usmani et al., "Effect of jujube honey on Candida Albicans growth and biofilm formation," Archives of Medical Research, vol. 44, no. 5, pp. 352-360, 2013.

[17] N. Al-Waili, A. Al-Ghamdi, M. J. Ansari, Y. Al-Attal, and K. Salom, "Synergistic effects of honey and propolis toward drug multi-resistant Staphylococcus Aureus, Escherichia coli and Candida Albicans isolates in single and polymicrobial cultures," International Journal of Medical Sciences, vol. 9, no. 9, pp. 793800, 2012.

[18] M. Moniruzzaman, M. I. Khalil, S. A. Sulaiman, and S. H. Gan, "Physicochemical and antioxidant properties of Malaysian honeys produced by Apis cerana, Apis dorsata and Apis mellifera," BMC Complementary and Alternative Medicine, vol. 13, article no. 43, 2013.

[19] V. Techtron, M. Amos, and V. T. Pty, Basic Atomic Absorption Spectroscopy: A Modern Introduction, Varian Techtron, 1975.

[20] M. N. Rashed and M. E. Soltan, "Major and trace elements in different types of Egyptian mono-floral and non-floral bee honeys," Journal of Food Composition and Analysis, vol. 17, no. 6, pp. 725-735, 2004.

[21] European Commission, "Method validation and quality control procedures for pesticides residues analysis in food and feed," Tech. Rep. SANCO/3131/2007, 2007.

[22] I. Amin, Y. Norazaidah, and K. I. E. Hainida, "Antioxidant activity and phenolic content of raw and blanched Amaranthus species," Food Chemistry, vol. 94, no. 1, pp. 47-52, 2006.

[23] C.-C. Chang, M.-H. Yang, H.-M. Wen, and J.-C. Chern, "Estimation of total flavonoid content in propolis by two complementary colorimetric methods," Journal of Food and Drug Analysis, vol. 10, no. 3, p. 178, 2002.

[24] S. T. Omaye, J. Tumball, and H. E. Sauberlich, "Selected methods for the determination of ascorbic acid in animal cells, tissues and fluids," Methods in Enzymology, vol. 62, pp. 1-11, 1979.

[25] N. Nelson, "Nelson-Somogyi modification colorimetric method for determination reducing sugar," The Journal of Biological Chemistry, vol. 153, pp. 375-380, 1944.

[26] O. H. Lowry, N. J. Rosebrough, A. L. Farr, and R. J. Randall, "Protein measurement with the Folin phenol reagent," The Journal of biological chemistry, vol. 193, no. 1, pp. 265-275, 1951.

[27] A. Braca, C. Sortino, M. Politi, I. Morelli, and J. Mendez, "Antioxidant activity of flavonoids from Licania licaniaeflora," Journal of Ethnopharmacology, vol. 79, no. 3, pp. 379-381, 2002.

[28] I. F. F. Benzie and J. J. Strain, "Ferric reducing/antioxidant power assay: direct measure of total antioxidant activity of biological fluids and modified version for simultaneous measurement of total antioxidant power and ascorbic acid concentration," Methods in Enzymology, vol. 299, pp. 15-27, 1998.

[29] Y. Bağci, D. Arslan, M. M. Özcan, and N. Dursun, "Determination of mineral contents of bee honeys produced in Middle Anatolia," International Journal of Food Sciences and Nutrition, vol. 58, no. 8, pp. 668-676, 2007.

[30] M. Akbulut, M. M. Özcan, and H. Coklar, "Evaluation of antioxidant activity, phenolic, mineral contents and some 
physicochemical properties of several pine honeys collected from Western Anatolia," International Journal of Food Sciences and Nutrition, vol. 60, no. 7, pp. 577-589, 2009.

[31] A. S. Alqarni, A. A. Owayss, A. A. Mahmoud, and M. A. Hannan, "Mineral content and physical properties of local and imported honeys in Saudi Arabia," Journal of Saudi Chemical Society, vol. 18, no. 5, pp. 618-625, 2014.

[32] M. A. Cantarelli, R. G. Pellerano, E. J. Marchevsky, and J. M. Camiña, "Quality of honey from Argentina: study of chemical composition and trace elements," Journal of the Argentine Chemical Society, vol. 96, no. 2, pp. 33-41, 2008.

[33] H. Yilmaz and Ö. Yavuz, "Content of some trace metals in honey from south-eastern Anatolia," Food Chemistry, vol. 65, no. 4, pp. 475-476, 1999.

[34] M. E. Conti, "Lazio region (Central Italy) honeys: a survey of mineral content and typical quality parameters," Food Control, vol. 11, no. 6, pp. 459-463, 2000.

[35] M. Moniruzzaman, M. A. Z. Chowdhury, M. A. Rahman, S. A. Sulaiman, and S. H. Gan, "Determination of mineral, trace element, and pesticide levels in honey samples originating from different regions of Malaysia compared to Manuka honey," BioMed Research International, vol. 2014, Article ID 359890, 10 pages, 2014.

[36] A. Pisani, G. Protano, and F. Riccobono, "Minor and trace elements in different honey types produced in Siena County (Italy)," Food Chemistry, vol. 107, no. 4, pp. 1553-1560, 2008.

[37] M. E. Conti and F. Botrè, "Honeybees and their products as potential bioindicators of heavy metals contamination," Environmental Monitoring and Assessment, vol. 69, no. 3, pp. 267-282, 2001.

[38] N. Bilandžić, M. Dokić, M. Sedak et al., "Determination of trace elements in Croatian floral honey originating from different regions," Food Chemistry, vol. 128, no. 4, pp. 1160-1164, 2011.

[39] T. J. Harshbarger and B. S. McGinnes, "Nutritive value of sourwood leaves," The Journal of Wildlife Management, vol. 35, no. 4, pp. 668-673, 1971.

[40] M. Tuzen, S. Silici, D. Mendil, and M. Soylak, "Trace element levels in honeys from different regions of Turkey," Food Chemistry, vol. 103, no. 2, pp. 325-330, 2007.

[41] R. Tsao, "Chemistry and biochemistry of dietary polyphenols," Nutrients, vol. 2, no. 12, pp. 1231-1246, 2010.

[42] L. Bravo, "Polyphenols: chemistry, dietary sources, metabolism, and nutritional significance," Nutrition Reviews, vol. 56, no. 11, pp. 317-333, 1998.

[43] G. G. Duthie and K. M. Brown, "Reducing the risk of cardiovascular disease," in Functional Foods: Designer Foods, Pharmafoods, Nutraceuticals, I. Goldberg, Ed., pp. 19-38, Springer US, Boston, Mass, USA, 1994.

[44] J. A. Milner, "Reducing the risk of cancer," in Functional Foods, pp. 39-70, Springer, Berlin, Germany, 1994.

[45] S. Bogdanov, T. Jurendic, R. Sieber, and P. Gallmann, "Honey for nutrition and health: a review," Journal of the American College of Nutrition, vol. 27, no. 6, pp. 677-689, 2008.

[46] N. C. Cook and S. Samman, "Flavonoids-chemistry, metabolism, cardioprotective effects, and dietary sources," Journal of Nutritional Biochemistry, vol. 7, no. 2, pp. 66-76, 1996.

[47] R. D. Hancock and R. Viola, "Improving the nutritional value of crops through enhancement of L-ascorbic acid (vitamin C) content: rationale and biotechnological opportunities," Journal of Agricultural and Food Chemistry, vol. 53, no. 13, pp. 52485257, 2005.
[48] A. C. Chan, "Partners in defense, vitamin E and vitamin C," Canadian Journal of Physiology and Pharmacology, vol. 71, no. 9, pp. 725-731, 1993.

[49] I. C. F. R. Ferreira, E. Aires, J. C. M. Barreira, and L. M. Estevinho, "Antioxidant activity of Portuguese honey samples: different contributions of the entire honey and phenolic extract," Food Chemistry, vol. 114, no. 4, pp. 1438-1443, 2009.

[50] G. Beretta, P. Granata, M. Ferrero, M. Orioli, and R. M. Facino, "Standardization of antioxidant properties of honey by a combination of spectrophotometric/fluorimetric assays and chemometrics," Analytica Chimica Acta, vol. 533, no. 2, pp. 185191, 2005.

[51] F. Buba, A. Gidado, and A. Shugaba, "Analysis of Biochemical Composition of Honey Samples from North-East Nigeria," Biochemistry \& Analytical Biochemistry, vol. 2, no. 3, article 139, 2012.

[52] K. A. Khan, A. A. Al-Ghamdi, and M. J. Ansari, "The characterization of blossom honeys from two provinces of Pakistan," Italian Journal of Food Science, vol. 28, no. 4, pp. 625-638, 2016.

[53] S. Saxena, S. Gautam, and A. Sharma, "Physical, biochemical and antioxidant properties of some Indian honeys," Food Chemistry, vol. 118, no. 2, pp. 391-397, 2010.

[54] E. M. Tanvir, R. Afroz, N. Karim et al., "Antioxidant and antibacterial activities of methanolic extract of BAU kul (Ziziphus mauritiana), an improved variety of fruit from bangladesh," Journal of Food Biochemistry, vol. 39, no. 2, pp. 139-147, 2015.

[55] R. Afroz, E. M. Tanvir, A. Islam, F. Alam, S. H. Gan, and I. Khalil, "Potential antioxidant and antibacterial properties of a popular jujube fruit: apple kul (Zizyphus mauritiana)," Journal of Food Biochemistry, vol. 38, no. 6, pp. 592-601, 2014.

[56] R. K. Kishore, A. S. Halim, M. S. N. Syazana, and K. N. S. Sirajudeen, "Tualang honey has higher phenolic content and greater radical scavenging activity compared with other honey sources," Nutrition Research, vol. 31, no. 4, pp. 322-325, 2011. 

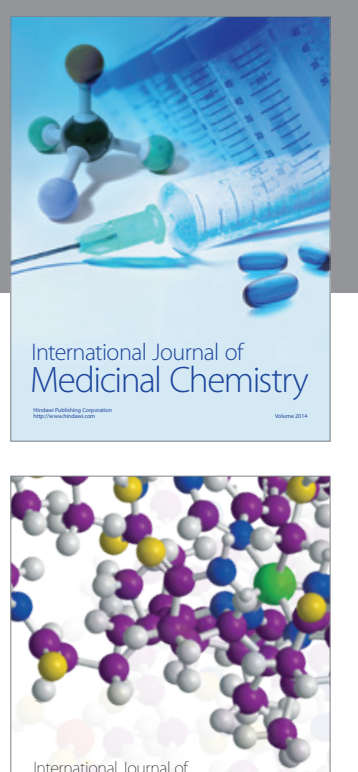

Carbohydrate Chemistry

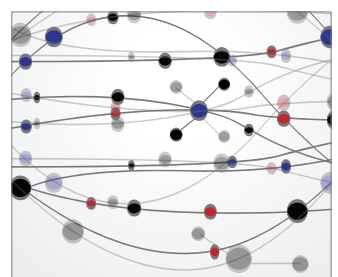

The Scientific World Journal
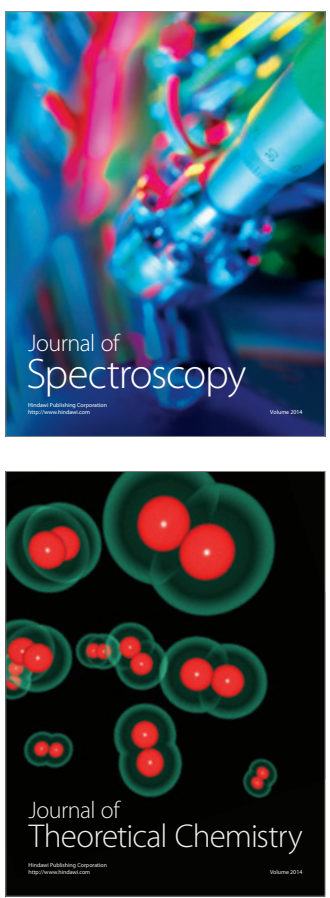
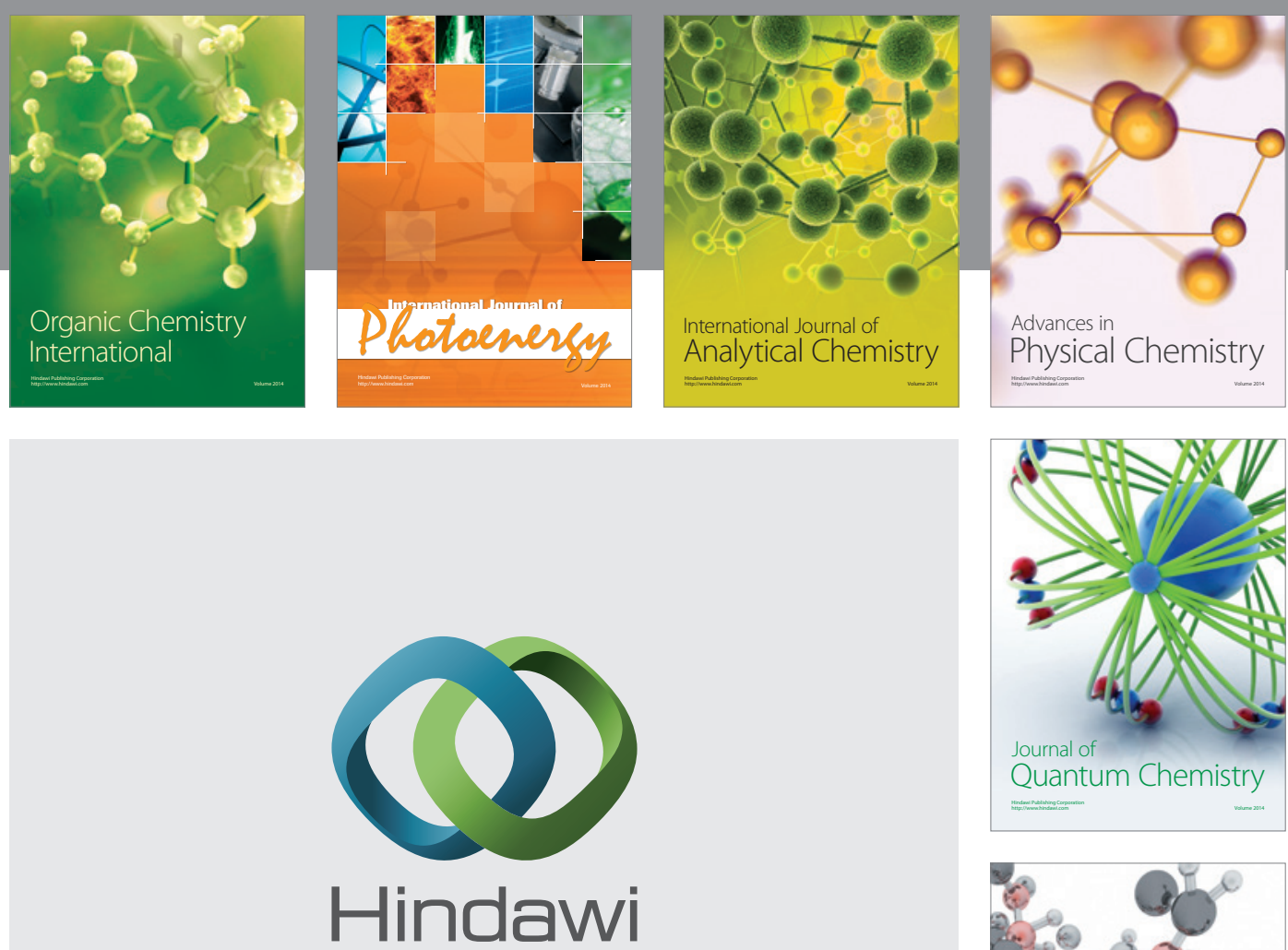

Submit your manuscripts at

https://www.hindawi.com

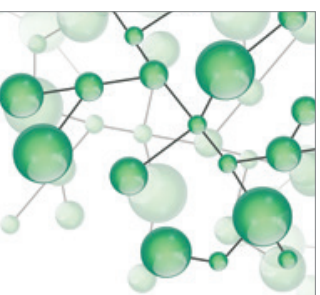

International Journal of

Inorganic Chemistry
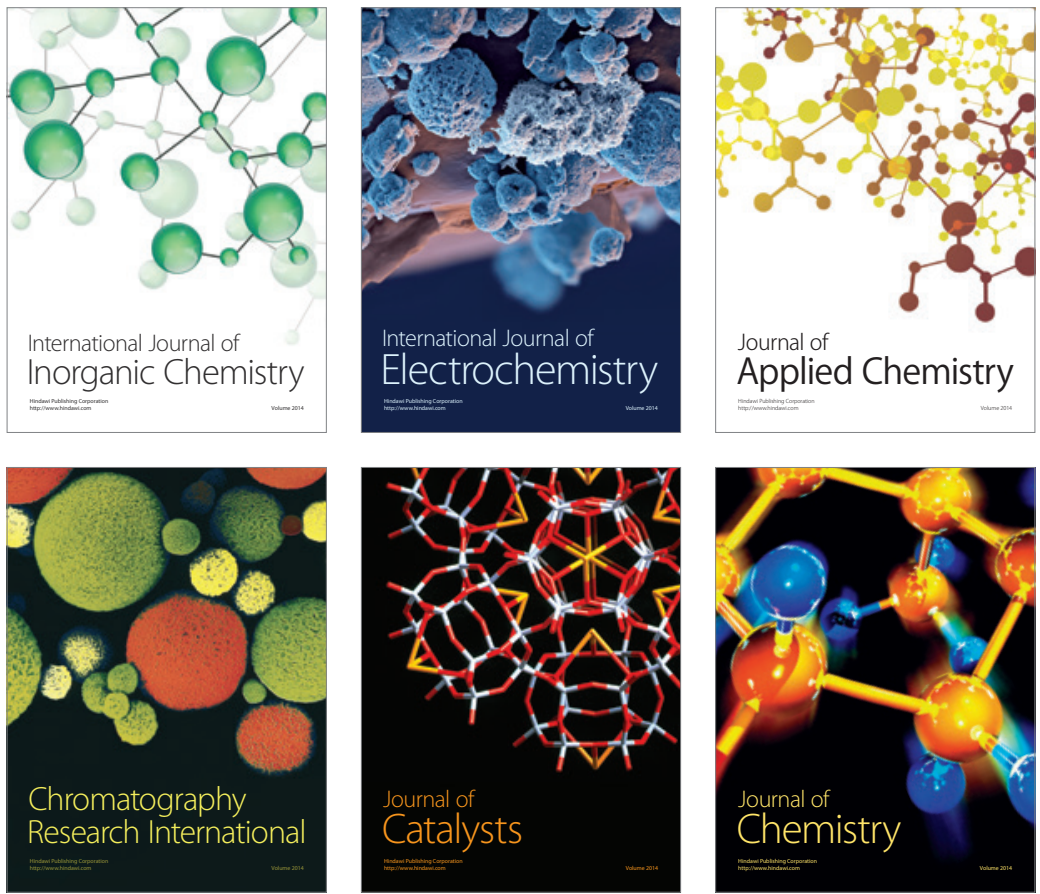

Journal of

Applied Chemistry
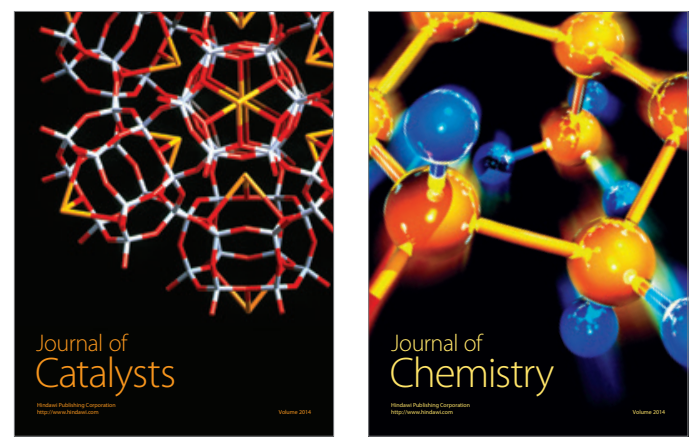
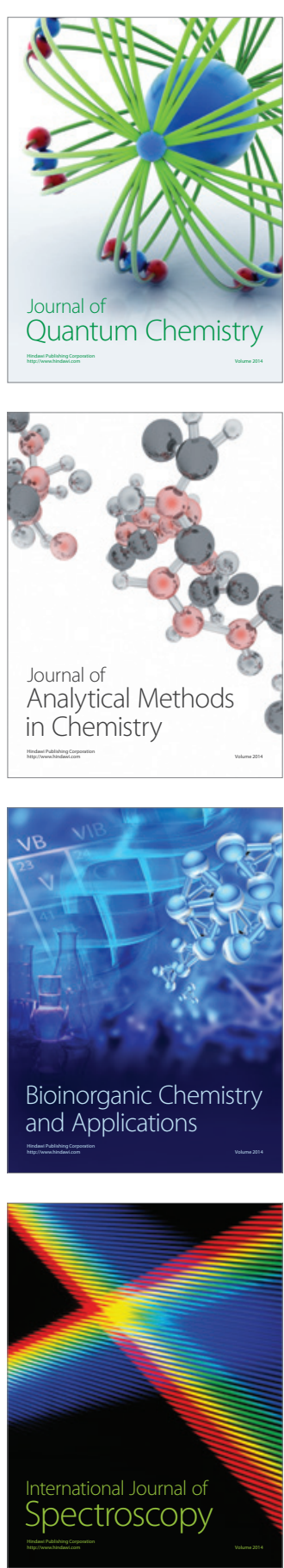